\title{
SOLYMÁR: AZ ARANYFALU ${ }^{1}$
}

\author{
(Solymár: the „Golden Village")
}

\section{VÁRADI MÓNIKA MÁRIA ${ }^{2}$}

\section{A siker csomópontjai}

Solymár a Pilisi-medence szép fekvésü, a fỏvárossal kőzvetlenül határos, Pesthidegkúttal jószerivel összeépullt falva, tőbb mint hétezer lakossal. A kőzség, szomszédaihoz, Nagykovácsihoz, Ürömhöz, Pilisborosjenőhöz, Pilisszentivánhoz, Pilisvőrösvárhoz és Hidegkúthoz hasonlóan a 17-18. században népesült be újra, német teruletekröl érkező telepesekkel. A Budai Hegyvidék sváb telepesfalvainak 19-20. századi fejlődését a főváros kőzelsége számos vonatkozásban meghatározta, alakította. Solymár, akárcsak a térség falvai, bekapcsolódott a fỏváros és vidéke munkamegosztási rendszerébe, mezógazdasági és kisebb részben ipari termékeivel (szén, kőpor, óntơdei homok) jelent meg a budapesti piacon. A filoxéra pusztítása után az Amerikából importált venyigék mellé mind tơbb gyümölcsfa csemetéjét ultették a solymári parasztemberek ${ }^{3}$; a gyümölcs váltotta ki a hajdan jól értékesíthető bort. A Buda környéki öszibaracktermő táj egyik legfontosabb településévé vált, ám nem barackjáról, hanem cseresznyéjéről híresült el Solymár. $\mathrm{Az}$ aszusodó, nem kukacosodó Politur, hiába vitték mindenfelé a kőzség faiskolájából, tán egész Közép-Európában nem termett meg sehol oly bő́ven, mint itt, "csak Solymár fantasztikus klímája és a meszes talaj volt jó neki".

Budapest és kőzvetlen vidéke közőtt már a század első felében kialakult egy másfajta, ha úgy tetszik, "modern" kapcsolat is. Solymáron, részint az ơröklési rend birtokaprózó gyakorlata, részint a föváros kỏzelsége miatt a két világháború kőzőtti korszakban is jelentős volt már az ipari népesség súlya. 1930-ban az 1.477 kereső 39,7\%-a, a 3.625 lakos 41,3\%-a élt az iparból ${ }^{4}$, ám a helyi ipar kezdeményei - a téglagyárak, a mészégetés, az öntődei homokszállítás - ellenére az ipari foglalkoztatottak 46,1\%-a, az osszes solymári kereső 23,4\%-a, 346 ember a föváros valamelyik nagyuzemében tudott elhelyezkedni ${ }^{5}$, a kor tudományos szóhasználata szerint "ingavándorló" volt. A jelentős arányú ingavándorlást megkönnyitették a kősség kedvező kőzlekedési feltételei; a faluközponttól egy kilométerre fekvő vasútállomásról 1895 óta indulnak vonatok Budapest és Esztergom irányába, és már a húszas években is naponta tobbbször fordultak a buszpárok Solymár és Hüvősvőlgy kỏzőtt. A szocialista modernizáció éveiben az ingázók aránya természetesen nővekedett, a fővárosi agglomeráció telepuléseihez hasonlóan az ingázás a helyi gazdaság és társadalom tipikus, ám Solymár esetében nem egyoldalúan meghatározó folyamatává vált. Abban, hogy a fơvárosi munkaerőpiac nem gyürte maga alá Solymár gazdaságát, igen nagy szerep jutott az 1959-ben alapított Pest megyei Múanyag- Játékáru és Tömegcikkipari Vállalatnak, a PEMÜ-nek, valamint a Pest megyei Vegyi és Divatcikkipari Vállalat, a PEVDI 6. számú gyáregységének. Solymárt az agglomerációs telepưlések egész sorától megkülönbözteti a relative 
erős helyi ipar; az említett üzemek a hetvenes-nyolcvanas években kb. 1000 helyi lakosnak biztositottak munkahelyet. A PEMỦ regionális munkaerôpiaci szerepe sem elhanyagolható, nem pusztán a szomszédos Pilisszentivánról és Pilisvőrösvárról jártak át a gyár üzemeibe dolgozni, hanem kủlön buszokkal hordták a munkásokat távolabbi, Komárom-Esztergom megyei településekről is. A kilencvenes évek fordulóján, mindenekelött a piacvesztés következtében, mindkét üzemnek súlyos gazdasági nehézségekkel kellett szembenéznie, amelyekkel, sikeres privatizációjának kőszönhetően, a PEMƯ tudott igazán megbirkózni. A PEMƯ RT a település legjelentósebb foglalkoztatója maradt, nyugati-magyar közös vállalataival együtt $\mathrm{ma}$ is félezer solymárinak ad munkát. $\mathrm{Az}$ a tény, hogy Solymáron jelentős ipar bontakozott ki, a helyi munkaeröpiacon valamelyest ellensúlyozni tudta a föváros elszívó hatását, s így lazított a Budapesttől való egyoldalú, $s$ az agglomeráció számos településére oly jellemzỏ függőségen ${ }^{6}$. A PEMƯ más szempontból is erős hatással volt a községre. Az üzem aktív kőzremúködése nélkül Solymár nem érte volna el a rendszerváltás idejére azt az infrastrukturális fejlettségi szintet, amely már a nyolcvanas években kiemelte az agglomeráció és Pest megye falvai kobzal. S ezen túl közvetett szerepe volt számos vállalkozás kibontakozásában is: a PEMÜ-ben tôltött évek jónéhány kőzépszintü végzettséggel rendelkezô, kőzépvezetỏi munkakörben dolgozó solymári számára jelentettek olyan inkubációs idöt, amelynek során fölhalmozott szakmai, kapcsolati tőkéjükkel sikeres vállalkozást indítottak el a kilencvenes évek elsó felében.

A telepúlésen meglévő ipari háttér, a fővárosi felvevơpiac kőzelsége, a telepulés infrastrukturális fejlettsége egyaránt hozzájárult ahhoz, hogy Solymár az agglomerációs települések körében is kimagaslónak számító vállalkozási aktivitást mutasson? . A helyi gazdaság erejét és ơnállóságát meghatározó megyei alapitású üzemek fejlődése kevéssé függött a fôvárostól, a kilencvenes évek sorản számban gyarapodó, tőkében és munkaerópiaci pozícióban izmosodó vállalkozásokról ez már nem mondható el, hisz a föváros kỏzelsége és a telepulés ill. a térség agglomerációs jellege biztosítja azt a széles és (relatíve) jómódú, fizetōképes fogyasztói kört, amely alapvető feltétele e vállalkozások megkapaszkodásának, gyarapodásának. Nem csupán s tán nem is elsósorban a solymári kőzönséget szolgálja ki az Opel, a Ford, a Mercedes autószalonok sora, vagy mondjuk a helyi ács kisvállalkozásból kinótt Fain építõanyag kereskedés. Az elmúlt évek egyik látványosan fölfutó vállalkozása, a közel negyven embert foglalkoztató Királyi Morzsák sütöde sikerét ugyan részben annak köszönheti, hogy hosszú évek után - 1973-ban, amikor Pilisvörösvárott fólépult a kenyérgyár, az utolsó solymári pék is bezárta sütơdéjét ${ }^{8}$ - ismét saját péksége és szaküzlete van a nagykőzségnek, az üzletmenet szempontjából nagyobb súllyal bír az a 110 viszonteladó a fỏvárosban, Pest megye településein, sôt Nógrád megyében, ahol a napi négy-öt tonna kenyér, 20-25 ezer darab péksütemény és kétezer finomsütemény zőme terítésre keruil ${ }^{9}$. Solymáron vagy száz vállalkozó kőtődik az épitőiparhoz, burkolóktól kezdve ácsokon át épitőipari vállalkozókig, az ő piacaik jelentős része is a községen kívuli található, a fôváros budai kerületeiben és az agglomerációhoz tartozó telepulléskörben.

Solymár legutóbbi ötven évének legmarkánsabb telepultésformáló folyamata a fövárosi lakónépesség folyamatos kiåramlása volt ${ }^{10}$. Talán a negyvenes évek második felének kivételével, amikor nagyobb számban érkeztek ide az ostrom alatt 
lakásukat vesztett hajógyári munkások a fövárosból ${ }^{11}$, meghatározónak a magasan kvalifikált értelmiségiek majd a vállalkozók, tehát jelentős gazdasági és kulturális tökével rendelkező társadalmi csoportok megtelepedése mondható. A kvalifikált és/vagy módos rétegek kitelepülése az agglomeráció preferált kisrégióiba és településeire (ilyen a Budai Hegység, a Dunakanyar, újabban a Zsámbéki Medence vagy a pesti oldalon Veresegyház és szomszédai) nem Solymárra korlátozódó jelenség, ám a nagyközség abban különbözik az összes többi érintett településtől, hogy a kitelepülés szakadatlan volt az elmúlt évtizedekben, és hogy a magasan kvalifikált népesség kiemelkedö jelenlétét, sürüségét eredményezte; a megfelelö korú népességben 17\% volt 1990-ben a felsőfokú végzettséggel rendelkezó nök és férfiak aránya, Solymárt egész Pest megyében Szentendre tudta csupán megelózni ${ }^{12}$. A gazdasági és kulturális tőke intenzív jelenléte a településen együtt jár a jövedelmi mutatók ugyancsak kimagasló értékeivel ${ }^{13}$. Solymár láthatóan sikeres település Magyarország egy sikeresnek mondott régióján, a fövárosi agglomeráción belül, iskolázottsági, vállalkozási, gazdasági, jövedelmi mutatói a budai agglomerációs altérségen belül is kiemelkedö értékekkel rendelkeznek. A siker nyilvánvaló és statisztikai mutatókkal megragadható jelei a különbözó tőkefajták massziv, folyamatos jelenlétére utalnak a településen.

A sikernek vannak olyan összetevői, amelyek a statisztikai megközelítés számára nehezen hozzáférhetők. Solymár, ez az agglomerációs település, úgy tủnik, eredményesen kerülte el a föváros közelségéból fakadó veszélyeket, nem lett alvófalu, s meg tudta ôrizni eredeti karakterét, kulturális hagyományainak javát, úgy, hogy közben a betelepülök igényeit, értékeit is integrálni igyekezett. A legkülönbözöbb egyesületek és alapítványok múködnek a faluban, az Apáczai Csere János Müvelódési Ház minden nap nyújt valamit a betérőknek ${ }^{14}$, Solymár kulturális, sport ${ }^{15}$ - és egyesületi életében több száz ember vesz aktivan részt, az egyes rendezvények ennél természetesen jóval tágabb kört érintenek. A tradíciók, értékek közötti egyensúlyra való törekvés jellemzi Solymárt, pezsgő kulturális és kőzösségi életének színeiben az alaptónust mégis a törzsökös sváb társadalom keverte ki. "Szerencse" is kellett ahhoz, hogy ez így legyen, ha ugyan szerencsének nevezhetó, hogy Solymárról "csupán" a németség felét telepítették ki 1946 szomorú, félelmekkel átszött tavaszán. A tradíciók megörzésében természetesen nem vesz részt mindenki, aki a sváb származási közösséghez tartozik, s nem is nézi minden solymári lakos jó szemmel a svábok (állítólagos) fölényét a falu életében, ki begyöpösödött, idejétmúlt zártságnak, ki arroganciának ítéli magatartásukat. Meggyőződésem azonban, hogy Solymár sikerének alkotóeleme, a közösség értéke, hogy sikerult megörizni a kulturális tradíciókat, valamelyest átmenteni a nemzetiségi identitás elemeit; ennek csupán egyik látható jele, hogy a hetvenes éveikben járó asszonyoknak úgy negyven százaléka nem öltözött át, az utcán, a nyilvánosság színterein ma is régi viseletuiket hordják. Ami a siker látványos részét illeti, Solymár az elmúlt években afféle sváb mintafalu lett, ide szervezik német, osztrák politikusok, legutóbb a német köztársasági elnök, látogatásait, a község nevét gyakran kapja fel az országos sajtó. Jóval mélyebb és tartósabb siker, hogy értékeivel, hagyományőrző tevékenységével a helyi társadalom nemzetiségi tagjai mércét, mintát kínálnak minden solymárinak, igazodni ehhez éppúgy lehet, mint elvetve, valami újat teremteni. Az az egyensúly, melyet én Solymáron érezni vélek, amely persze ingatag és korántsem örök, e folyamatos és termékeny kölcsőnhatásból fakadhat. 


\section{A falu rajzolatai}

Pesthidegkút felöl érkezve a Kakukkhegy meredek oldalán kapaszkodó, hivalkodó családi házakat, csupa-üveg villák foltjait pillantja meg előszőr a látogató. A kőzséget délről övezö hegyek oldalán nyugat felé, végig a Kerekhegyen, a Zsíroshegyig a házak egyre magasabbra kúsznak az erdőben, e hegyek északi lejtójéröl pazar kilátás nyilik a Pilisi Medencére és a völgyet lezáró hegyekre. A természeti környezet is vonzza azokat, akik a György- vagy Kerekhegyen szereztek maguknak építési és ủdülőtelket. Csak a beépités jellege változik, a Györgyhegyet a sürủ családi házas utcabeépítés jellemzi, itt a természetes növényzet is gyér; a Kerekhegy fokozatosan válik hétvégi telkes területböl kertvárosias településrésszé; itt nagy, erdei fákkal teli telkek kerültek fölparcellázásra. A dombos falu központja, noha hovatovább városias gépjármúforgalmat bonyolít, megörizte eredeti karakterét: a Templom tér neve németül is kikerült a táblákra, községi rendelet tiltja a volt paraszt, iparos polgárházak, mint a kultúrházként müködő hajdani Schäfferkocsma eredeti szerkezetének megbontását, stílusának átalakítását. Igaz, az iskola új épülete is itt épült meg, akárcsak a posztmodern jegyeket mutató üzletsor, ám a hatalmas gesztenyefák jótékonyan takarják az elütő stílusjegyeket. A század derekára fokozatos utcamegnyitások révén kialakult faluban az elmúlt évtizedek során a régi egyszerủ vagy újabb tornácos sváb parasztházak helyére, esetleg mellé, többnyire emeletes, jómódról tanúskodó családi házakat emeltek a sváb öslakosok és a betelepített alföldi, felvidéki magyarok leszármazottai. A sürü belterületi beépítést részint a telekárak magyarázzák, részint a különösképpen a sváb családokban jellemzö összetartás, közülük sokan törekedtek arra, hogy a gyerekek a nagy, nyeles telekké alakított udvarokon, ha erre nincsen mód, legalább azonos utcában építkezzenek, maradjanak a közelben. A hatvanas-hetvenes években megindult a falukőzpontból való kihúzódás folyamata is, igaz nem messzire, csak a (hajdani) gyümölcsösökbe, a falu északi részén, a kőzponttól egy kilométerre fekvö vasútállomáshoz vezető út mentén. Ez a családi házas utca átmenêt nélkül nekiszalad a lakótelepnek és a PEMÜ épülettömbjének, a lakóházak és az üzem lapos kockaépületeikkel egymással harmonizálnak ugyan, a falu összes többi részétöl elütnek, amolyan idegen testként húzódnak a falu északi oldalán. A parkosításnak köszönhetöen azonban a mindösszesen 560 lakást számláló telep néhány épületének kopottsága az év nagy részében nemigen látható. Azután, a falu határát jelző tábla és egy-egy ipari telephely után, a Pilisszentivánra vezetö út mentén a Zsíros-hegy oldaláig fôlkúszó Hutweide vegyes képlete következik: kis bodegák a kerti szerszámoknak, hétvégi nyaralók, családi házak, s üres telkek, gyümölcsös kertek.

Beszélgetésekben, újságban, mint állandó motívum ismétlődik a mondat: "azt mondják, a község fejlett, a környéken kimagasló infrastruktúrája a telekértékesitéseknek volt köszönhetôn ${ }^{16}$ A parcellázások és az infrastruktúra megépülése között nyilvánvalóan létezik összefüggés, ám nem pusztán a fenti mondat értelmében, hogy ti. a községi kasszába úgymond leginkább tengernyi pénz folyt az építési ill. uudülötelkek értékesítéséből. Nem a község volt ugyanis az egyetlen érintett tulajdonos, $\mathrm{s}$ úgy túnik, ahol a terület a tulajdonában állt, a kisajátítást is a kivitelező bonyolította; ez történt a PEMÜ-lakótelep építésekor. Itt 
olcsó lakáshoz jutottak a vállalat dolgozói, ám csak a lakásoknak egy része épült munkahelyi kölcsön konstrukcióban, s hamarosan a Pest megyei OTP vette át az építkezést, a lakások egy részét a HM dolgozóinak értékesítve. $\mathrm{S}$ az ún. PEMÜlakótelep mellett a nyolcvanas években a Rozmaring Mgtsz, valamint a Fövárosi 1. számú Építooipari Vállalat kezdett lakásépítésbe. Ekkorra azonban az alapinfrastruktúra kiépült a kơzségnek e részén; a PEMÜ csak az alapközmüvek biztosításával vághatott bele a lakásépítésbe. Solymár községnek ez azt jelentette, hogy a földgáz, a szennyviz-csatorna gerincvezetéke a hetvenes-nyolcvanas években megépült; az 1972-ben megalakult Solymári Vízmü Társulat egy év múlva egyszersmind Csatornamü Társulat lett. Ebben az idöben elkészült a szennyvíztisztitó telep is, melyet később bővíteni és korszerüsíteni kellett. Az új szennyvíztisztító üzemet, valamint a csatornarendszert 1995 óta Solymár és Pilisszentiván község közösen müködteti. Az elkészült gerincvezetékeket a községi központ felé bővitették tovább, s a lakótelep mellett a község összes lizemét és tanácsi intézményét bekapcsolták az alap infrastrukturális ellátásba, s a vezeték mentén fekvő ingatlanok tulajdonosainak módjuk volt rákapcsolásra.

Solymár kedvelt kirándulóhely volt századunk elején, a büzơs város elöl már akkoriban is kirajzani vágytak a friss erdei levegőre a városiak, egynehány nyári villalakás is megépült a faluban. Az üdülöterületek parcellázásának már a második világháború éveiben nekirugaszkodtak a község földesurának, az 1933-ban elhunyt gróf Karácsonyi Jenónek örökösei, ám a háború és a földreform elsodorta a parcellázási terveket és a telektulajdonosokat, az erdők az állam kezébe kerưltek, $\mathrm{s}$ ennek megfelelóen az állam, illetve a járási és megyei tanácsi szervek kezdték meg az üdülőtelkek parcellázását és építését. A községi lakosok a hetvenes években kapcsolódtak be ebbe a folyamatba, s részesedtek a község bővülésének anyagi áldásaiból, ekkor ugyanis a Hutweide, a valamikori szőlős- és gyümölcskertek parlaggá sivárult területe került már sorra. Az utolsó nagy parcellázást a Rozmaring Mgtsz hajtotta végre a nyolcvanas évek elején; a község keleti részén fekvő Györgyhegyen megnyitott Ibolya utcával; a községvezetés, azután az újonnan építkezó lakók számára suttyomban lehetővé tette, hogy mindazok, akik az utca mellett levezetö csatorna közelében laknak, kedvezö áron ráköthessenek. Az infrastruktúra és a község külterületeinek növekvő mértékủ parcellázása ugyanis abban mutatja a legszorosabb összefüggést, hogy a beköltözők az üdülöterületen is egyértelmủen igényt tartanak a telkek ill. lakások összközmüves ellátására. Ennek érdekében a község gyors ütemben benépesủlő zártkertes és üdülöterületein a lakók kezdettöl társulásokat hoztak létre, s gyakran nem kevés, több tízezer forintos terhet vállalva építettek utakat, vezették be a vizet telkeikre, kötöttek rá a gázvezetékre.

1995-ben a solymári lakások $88,6 \%$-a volt bekapcsolva a közüzemi vízhálózatba, $25,2 \%$-a a közcsatornahálózatba, és $94,1 \%$-a volt vezetékes gázfogyasztó. Ugyanebben az esztendóben 2.305 távbeszélő fövonal élt a településen (ezer lakosra 318 fövonal jutott), a lakásállomány 2.490-re rúgott ${ }^{17}$, a közintézményeket és az azóta tartó folyamatos bekötéseket is figyelembe véve helytálló a polgármester által becsült 95\%. Ha az 1990-es állapotot tekintjük kiindulópontnak, a vízhálózat kivételével minden területen hátra volt a közmúépítés java. A fejlödés ezen a településen is az 1990 és 1994 közötti években volt a leglátványosabb, igaz, az induló állapot és a lakosság együttmüködési szándéka, anyagi áldozatvállalása az 
agglomerációhoz tartozó települések többségénél is kedvezőbb feltételeket teremtett e fejlödéshez. A gáz csak a Hutweide üdülöterület magasabban fekvő részein nem épült ki - Solymár domborzati viszonyai jelentösen megnehezítik és lassítják a közmúépítést. A csatorna megépítésére csak másodszori nekifutásra sikerült elnyerni a harminc százaléknyi állami részt; az első ütem a tervek szerint befejezödik 1997 decemberéig, a beruházás nettó összege 268 millió Ft, a második ütem várhatóan 1999 végén, 300 milliós költséggel zárul; a kieső részek, a Hutweide és a Kerekhegy területén további 470 millió Ft forrás lenne szükséges. Az útépítés területén már a tanácsi rendszerben élenjárt Solymár, 1990-ben a belterületi utak $75 \%$-a aszfaltozott volt, a jelentós folldmunkákat igényló beruházások óta csak ott aszfaltoznak, ahol a csatorna is megépült; a lakossági hozzájárulás összege ma már 70 ezer $\mathrm{Ft}$.

A beköltoözők jelentős mértékü anyagi áldozatvállalása a lakókörnyezet minőségének kialakitásában nyilvánvalóan tükrözi vagyonosságukat, és anyagi helyzetüktől többnyire elválaszthatatlan igényességüket is. Az infrastrukturális ellátottság, a kényelem iránti igény mintha átrendezni látszana az ingatlanpiacon megjelenő keresletet is. Jelenleg leginkább a község keleti és északi oldalán megkezdett utcák iránt nagy az érdeklödés, a friss hegyi levegö, a fákkal teli nagy telek inkább egy-egy fölbukkanó müvészlélek igénye. Az ingatlanirodában érdeklődő ügyfelek elsősorban vállalkozók, az általuk keresett lakás "legyen ủj, szép és drága". Egy összközműves telek négyszögöle 25-30 ezer Ft körül kapható, az ủdülőterületen, ahol a gáz nincs bevezetve, 12-18 ezer Ft között is elkérnek egy négyszögölért. A solymári árak 25-30\%-kal magasabbak, mint a szomszédos településeken: a növekvő népességủ és teljes közmüvekkel rendelkező Pilisszentivánon vagy a Pilisi Medence kistérségi központjában, a várossá avatott Pilisvörősvárott. Aki azonban Solymárra jön tájékozódni, már nem megy tovább; a lakókörnyezet, a község szép fekvése, valamint a jó közlekedési viszonyok Solymár mellett szólnak. Az ingatlanárak a falu központjában sem alacsonyabbak, ott azonban kevés az eladó épület. Solymáron azok kínálják eladásra házukat, tơbbnyire idősek, akik már nem tudják a fönntartás költségeit állni, ám ök is a községben szeretnének egy kisebb házba költözni; kisebb ház azonban itt nemigen akad. A fövárosiak folyamatos érdeklödése, a kedvezö ingatlanpiaci viszonyok a lakótelepi lakások árait is kedvezöen befolyásolják; rögtön elkel az a lakás, melyet megvételre kínálnak, még ha meglehetösen elhanyagolt állapotban van is, ötvenezer forintot fizetnek négyzetméteréért, egy felújított lakásban hetvenezret ér egy négyzetméter. A polgármester - maga is lakótelepi lakos - a lakótelepben egy emberőltő múltán robbanó idözített bombát lát, a jelenlegi helyzet azonban nem indokolja borúlátását. Egy-egy szegényebb, a közös költségeket fizetni nem tudó család ma is fölfölbukkan itt, a többséget, a lakótelepen élök magját mégis értelmiségiek, fömérnökök, vállalkozók alkotják, akikben "megvan a solymári öntudat", ami rendszeretetet, szorgalmat, igényességet jelent. A lakótelep társadalmi karakterét meghatározó értelmiségi és vállalkozó csoportok, valamint a magas ingatlanárak jelenleg sikerrel állják útját a szegregációnak, a telep slumosodásának. A község állandó szociális támogatásban részesülö szegényei, vagy 100-150 ember, föként az idös betelepültek közül való, akik még a hetvenes-nyolcvanas években építettek itt kis hétvégi házat, ügyelve arra, hogy nyugdijas éveikre állandó lakhatásra is 
alkalmas legyen. Idős kisnyugdijasok a faluban is vannak, de a sváb öslakosság körében "érezhetó a család megtartó hatása, kevés az a sváb család, ahol akár egy egyedülálló öregasszony eljönne ide segélyért".

A Templom téri ingatlanirodában az elmúlt két évben a forgalom megcsappanását érzékelik; érdeklődő van ugyan elég, ám tíz esetből általában egy-két adásvétel, ha létrejön. Részint a magas és emelkedỏ ingatlanáraknak tudható be e tény, részint az értékesíthetỏ telkek apadó számának. Nagyobb számban a Hutweide üdülöterületén lennének eladó üres telkek, ám az élénk piaci forgalomnak útját állja a gáz hiánya és a község településfejlesztési elképzelése. Az önkormányzat ugyanis osztja jónéhány solymári polgár aggodalmát, félelmét attól, hogy Solymár "idomtalan, se falu se város" település ${ }^{18}$ lesz, s elejét kívánja venni a nagyközség további terjeszkedésnek. A jelenlegi belterületi határon már nem kíván változtatni, az üdülöterületet nem kívánja átminősíteni. Ha ugyanis ez megtörténne, akkor a fővárosiak "iszonyú áradata" lepné el a falut, és ez hatalmas anyagi terhet jelentő feladatok elé állítaná az önkormányzatot, föként az oktatási és egészségügyi ellátás területén, biztos fedezet nélkül. Föltehetően az őslakos telektulajdonosok azok, akiknek érdekeit e korlátozás sértheti, olyannyira, hogy a polgármester szerint a következỏ választások egyik sarkalatos kérdése lesz a község belterületi lehatárolásának ügye.

\section{Önkormányzati cselek - polgári erőfeszitések}

1991-ben Solymáron 1.961 lakóház és 1.356 üdülöház álltt ${ }^{19}$, az udülöházakként nyilvántartott épületek egy részét azonban már akkor is állandóan lakták az ideiglenes be- vagy egyáltalán be nem jelentett lakók. Bármilyen jómódúak is Solymár lakói, $\mathrm{s}$ legyen bármilyen irigylésre méltó az itt élók által befizetett személyi jövedelemadó nagysága, az önkormányzati gazdálkodás szabadsága ebben a nagyközségben is korlátozott; a központi támogatás mértékének csökkenésével az intézmények müködtetésének önkormányzati részesedése növekedett, ma átlagosan $40 \%$. Alapvető települési, oktatási, kulturális és egészségügyi, emellett fejlesztési feladatainak ellátáshoz saját források után kellett néznie a képviselótestületnek. Ennek jegyében vezette be még 1994-ben a vállalkozók iparúzési adóját, majd 1995 decemberében a helyi adórendelet módosításával a vállalkozók kommunális adóját is. A bevétel növelésének másik útjaként, $s$ egyben a település fejlödéséröl kialakított községi koncepció szellemében a testület megpróbálkozott az udulöterületeken élőket is különféle befizetésekre ösztökélni, azon szolgáltatások téli hóeltakarítás, szemétszállítás, kátyúk rendbetétele, stb. - ellentételezéseként, melyeket az ơnkormányzat az itt élöknek is nyújt. Az idegenforgalmi adó 1992-es bevezetése - évi $150 \mathrm{Ft}$ négyzetméterenként - nem aratott túlzott sikert és jelentős bevételeket sem eredményezett. A képviselőtestületet azonban nem lehetett szándékától eltántorítani. Megbizásából az önkormányzati hivatal szúrópróbaszerủen megvizsgált néhány utcát, hogy felmérje, hányan laknak ott "életvitelszerüen", majd a "szükségbốl (tehát a növekvő lakosságszámból) erényt" kovácsolva, az idegenforgalmi adó eltörlésével egyidejüleg az egész község terulletén bevezette az épitményadót. Az állandó bejelentett solymári lakosok számára azonban $90 \%$ kedvezményt nyújt, így igyekezvén a faluban élöket bejelentkezésre bírni, s ezzel az állandó lakosságszám után fizetett normatív állami támogatás és a községben maradó személyi jövedelemadó ơsszegének növekedését elérni. 
Úgy tünik, e törekvést siker koronázza - a hasznos alapterület minden egyes négyzetmétere után $700 \mathrm{Ft}$ fizetendö, ez a solymári házak nagyságát tekintve jelentős összeget jelent - a polgármester szerint az elmúlt két évben négyszáz fỏvel emelkedett a falu állandó lakosainak létszáma, s meggyőzỏdése, ha minden ủdülőterületi lakos bejelentkezne - ha csak hétvégenként jár is ide -, a nagyközség lélekszáma meghaladná a tízezret.

A községi képviselötestület azonban nem csupán kér, hanem nyújtani is igyekszik valamit, komolyan véve az 1994-es választási kampány során és a beiktatásakor tett igéretét, mely szerint müködésében a nyíltság és nyitottság elve vezérli majd. Mindezzel nem valami új dolog jelent meg a solymári községvezetés gyakorlatában. A tanácsrendszer utolsó éveiben, amikor egyesületek és pártok itt is újra kivirágoztak, a tanácselnök-asszony, a felettes állami és pártszervek berzenkedése dacára, az újonnan alakult társadalmi szervezetek elött nyitottá tette a tanácstestület, sőt, a végrehajtó bizottság munkáját, az anyagokat megküldte és véleményezési jogot biztosított számukra. 1990 és 1994 között elvileg semmi nem változott, ám az akkori polgármester és a képviselök között mindinkább kiéleződỏ konfliktus nem kedvezett a nyílt légkör virulásának. Az 1994. decemberi választások után a testulet újra felvette a kapcsolatot a község szervezeteivel, a komoly bázist nélkülözö pártokkal, az egyházakkal, egyesúletekkel; megbízottaik az ulléseken és a bizottsági munkában egyaránt részt vesznek (vehetnek). A nyiltság jegyében az éves költségvetések végsỏ elfogadása előtt az elképzeléseket lakossági fórumon tárják a solymári polgárok elé, és müködésének második éve óta a testulet kéthetente fogadóórát tart, hogy az üléseken meg nem jelenő solymáriak ügyes-bajos dolgaikkal fơlkereshessék választott képviselöiket. Más kérdés, hogy a polgárok érdeklődése meg-megcsappan, erröl tanúskodnak a polgármester vagy egy-egy képviselötársa helyi sajtóban alkalmanként megjelenő elmarasztaló szavai.

A nagyközség társadalmi szervezeteinek, katolikus és református egyházának, egyesületeinek bevonásával a képviselőtestulet az érdekegyensúly megteremtésére törekszik döntéseinek előkészítésében, és ugyanezen egyensúlyra, no meg a növekvő számú lakossággal való hatékony kapcsolattartásra való törekvésként értékelhető a különböző telepưlésrészek egyesületeinek bevonása a képviselötestület munkájába. Jelenleg három ilyen egyesület müködik a nagyközségben Györgyhegyen, Kerekhegyen és Hutweidén - nem elözmények nélkül, hisz mindhárom részen társultak ill. folyamatosan társulnak a lakók valamely közmü bevezetésére ill. közös feladat megoldására. Müködésük intenzitása és jellege persze eltérö, $\mathrm{s}$ attól is fugg, mekkora az érintettek köre; a négy, igaz meglehetösen hosszú utcából álló Györgyhegyen az egyesület vezetőjének és tagjainak utcabálok szervezésére is futja energiából és kedvböl, a Kerekhegyen lakó közel 900 ingatlantulajdonos autóbusz-fordulót épített és az önkormányzattal közösen elérte, hogy egy vállalkozó buszjáratot üzemeltessen a területen, a Hutweide Társaságnak azonban nem sikerult elérnie, hogy mind a 650 tulajdonos befizesse az útépitéshez kért tízezer forintos hozzájárulást ${ }^{20}$. Bármit is tudjanak azonban ezen egyesületek szervezettségben, kohézióban, eredményességben fơlmutatni, létük önmagában eredmény, vagy mondjuk így: siker, hisz hozzájárulhatnak ahhoz, hogy a különböző településrészek megfogalmazzák és a nyilvánosság előtt megjelenítsék a nagyközség más részeitől, hol különböző, hol azokéval egyező bújukat-bajukat, érdekeiket, hogy 
kialakítsák és fölmutassák saját identitásukat. Áldozatvállalásukkal, szervezödésükkel e településrészek lakói egyúttal kifejezik azt a tényt, hogy, legyenek akár friss betelepültek, akár hétvégi pihenókből fokozatosan állandó lakókká avanzsált fơvárosiak, akár nyugdíjasként hosszú évek után kis házakba visszatérő "régi" solymáriak, önmagukat Solymár polgárainak tekintik, és azt az igényt is, hogy az őslakos, törzsökös solymáriak öket ekként elfogadják.

A "faluban", amely a helyi szóhasználatban lényegében a sváb ófalut jelenti, nem alakult külön településrészi egyesület, s erre nincs is szükség, hisz eltérő karaktere nem csupán építészeti stílusjegyekben nyilvánul meg, hanem az itt élök összetartozásában, még nyelvhasználatban, nemzetiségben asszimilálódott egyéneinek habitusában és származástudatában is tetten érhetỏ sajátosságokban, és abban az erőfeszítésben, hogy tradícióit megőrizze és továbbadja. A lakótelepen élök ugyancsak nem szerveződtek településrészi közösséggé; az itt élöket nem füzi egybe a származási közösség tudata, a hetvenes években a munka- és az akkoriban kedvező lakhatási lehetőségek csábították ide a PEMÜ szakembereit, egy évtizeddel később a kellemes lakókörnyezet és az üdülöövezetnél kedvezőbb árak a fóvárosba ingázó, vagy valamely helyi intézményben dolgozó értelmiséget, $\mathrm{s}$ a falunak ebben a részében az alapvetö infrastrukturális szolgáltatásokért sem kell összefogni.

A képviselőtestület és a nagyközség különféle érdekcsoportjainak egyutttmüködése nem föltétlenül halad egyenes, zökkenők nélküli utakon, erre a vállalkozók szolgáltatják a legkézenfekvőbb példát. Solymáron a helyi vállalkozói elit már a kilencvenes évek elején megszerveződött, a Privát Profit helyi klubjának megalakulása azonban csupán a kiválasztottak exkluziv körének jelentett inkább baráti társaságot mintsem érdekvédelmi szervezetet; a falu központjában megnyitott söröző csak klubtagok számára állt nyitva, a klubprogramok hatása sem gyürủzött szét a helyi vállalkozói körben, nem szólva a helyi társadalom más csoportjairól. 1994-ben hat vállalkozó Solymári Választási Szövetséget alkotva indult a helyhatósági választásokon, egyikük sem solymári születésü, valamennyien az elmúlt évtizedekben vagy éppen években költöztek ide; ők azután az 1995-ben megalakuló Vállalkozók Egyesületének alapitó tagjai közé tartoztak. A Szövetségböl egy jelölt jutott a testületbe, a Királyi Morzsák sütöde tulajdonosa, sikeres és adakozó kedvü ${ }^{21}$ vállalkozó. A 14 fős testületben mindazonáltal kilenc vállalkozó ül, a legváltozatosabb foglalkozásokban; kereskedő, magántervező, vállalkozó orvos egyaránt megtalálható közöttiik, négy képviselỏ éppen a választás évében vágott bele ơnálló tevékenységbe. A képviselötestületben a vállalkozói kör alkotja a meghatározó csoportot, és ez kifejezi ugyan a vállalkozók helyi gazdaságban és társadalomban elfoglalt pozícióját, erejét, ám, szerencsére nem vezetett a testületen belül egyoldalú preferenciákhoz, a vállalkozói képviselói kör dominanciájához. A vállalkozóként tevékenykedők képviselői minőségükben kénytelenek voltak szembesülni azzal, "hogy az állam, gondjainak megoldása érdekében "lepasszolja" a finanszírozási hiányok pótlását a községekre", és "tudomásul kell vennün, hogy egyre inkább a saját lábunkon kell megállni", s igy ók is elkerülhetetlennek látták s megszavazták a helyi adók kivetését.

Sajátos módon ahhoz, hogy a helyi vállalkozói elit kilépjen az exkluzív elzárkózásból a nyilvánosság terepére és autonóm erővé szerveződjön, szükség volt az óket sújtó adók bevezetésére. Az iparúzési adó bevezetése sokáig, 
1994. január 1-től 1995 szeptemberéig visszhangtalan maradt. Ekkor neszelt föl a '95 tavaszán 11 fỏvel megalakult Solymári Vállalkozók Egyesülete, s irt levelet a képviselótestulletnek. Sokallta ugyanis a nettó árbevétel után befizetendő 8 ezreléket, mondván, hogy ez "néhány esetben majdnem akkora összeg, mint az éves nyereség", továbbá, hogy a testület nem konzultált velük, noha a választási kampány során egészen mást ígért, s hogy " a helyi vállalkozók mindig is kiveszik a részüket a közösségi célok anyagi megteremtésébōl, esetenként, folytatólagosan, vagy alapítványok részeseiként". A vállalkozók kérték, hogy a testullet nevesítse az általuk befizetett adó "hovafordításának célját", hogy tehát a Vállalkozók Egyesủlete úgymond társadalmi ellenőrzést gyakorolhasson a vállalkozók által befizetett adó ủjraelosztása fỏlött. Az utóbbi kívánalmat a polgármester és a testulet megalapozatlannak és veszélyesnek tartotta, mert ez a fajta ellenörzés korlátozná a testület gazdálkodási önállóságát. Ugyanakkor, bár a polgármester némiképp feddö hangon szólt a vállalkozók eleddig tanúsított passzivitásáról, hamarosan ơsszeủltek a testület és a vállalkozók képviselöi, hogy afféle csúcstalálkozó keretén belül egyeztessék érdekeiket. A tárgyalások eredményeként megszủletett az önkormányzat és a Vállalkozók Egyesülete közötti együttmüködési megállapodás. $\mathrm{Az}$ Egyesủlet delegált tagjai révén aktîv szerepet vállalhat az önkormányzati üléseken, valamint a pénzügyi és müszaki bizottságban, a községi beruházások pályázati kiírásait megkapja, a kontárok és a fekete munka elleni küzdelem frontján közősen kép fel az ơnkormányzattal. A még ma is meglehetősen szükkörü, a helyi vállalkozói és menedzser elitet tömörítő társaság legfontosabb eredményének azt tartja, hogy az 1995-ös helyi adórendelet bevezetése óta a testület nem emelte a vállalkozókat sújtó terhek mértékét. Ez a rendelet differenciál a tevékenység jellege szerint, termelỏ tevékenységet folytatók nettó árbevételuk 7, kereskedők 9 ezrelékét kötelesek a községi kasszába befizetni, és meglehetősen nagyvonalúan vonja meg az adókedvezményben részesíthetók körét; munkahelyteremtő, ipari tanulókat foglalkoztató vállalkozó éppúgy kedvezményezett, mint az, aki az önkormányzat által is támogatott alapítványokat szponzorálja, stb. Az önkormányzat mindeközben nem volt rest, hogy az adóhatóság bevonásával kiderítse, hány vállalkozó is dolgozik a telepulésen; 1995 nyarán mindössze 682 bejelentett vállalkozás múködött Solymáron, melyek közül 419 nyújtott be adóbevallást, egy év múltán a testullet örömmel vette tudomásul az APEH közlését, miszerint a községben 1100 vállalkozó tevékenykedik. A folyamatos hivatali ellenőrzésnek köszönhetően a vállalkozások által befizetett iparúzési és kommunális adó összege évről évre emelkedik; míg 1995-ben 22 millió forint folyt be a községi kasszába, addig 1997 ben már 60-65 millióval számol a polgármester, az 1996-os nagykőzségi költségvetés bevételi tételei között a helyi adók tíz százalékot tettek $\mathbf{k i}^{22}$.

Az egyelöre huszunkét tagot számiáló Vállalkozók Egyesủlete 1997 őszén látta elérkezettnek az időt arra, hogy kilépjen a község nyilvánossága elé; az együttmúködési megállapodás, a testuleti és bizottsági munkában való aktív részvétel révén stabilizálódott pozíciója a helyi közéletben, e pozíciót és a vállalkozói kör öntudatát, önbecsülését erösíti a különböző egyesületek, solymári rendezvények anyagi támogatása ${ }^{23}$. 1997. szeptemberétől rendszeresen megjelennek majd a Solymári Hírmondó hasábjain, októberben tagtoborzó Nyílt Napot tartanak, és megkezdték az elökészületeket a kővetkezỏ évi választásra, mindenképpen 
kívánnak egy jelöltet bejuttatni a képviselötestületbe. A Vállalkozók Egyesületének önálló érdekcsoportként való fóllépése jelzi, hogy a kapitalista viszonyok térhódítása úgy ment végbe a helyi gazdaságban, hogy a gazdasági elit, mikőzben elfoglalta pozícióit a helyi hatalmi szerkezetben, egyúttal a kőzélet differenciálódásához, a gazdaság és politika szféráinak (legalább formális) szétválásához is hozzájárult. Egyesủletek, községi ünnepek és rendezvények szponzoraként a vállalkozói réteg sikerrel igyekszik presztízsét, szimbolikus tőkéjét növelni, amelyet azután politikai és anyagi tỏkévé alakíthat át.

\section{PEMÜ: sikertörténet?}

A solymári ipar lényegében a falu határán túl nem lépỏ szolgáltató kisipart jelentette, "leginkább egymásnak dolgoztak"; bizonyára nem tekinthetó véletlennek, hogy 1951 nyarán, amikor a megszorító intézkedések végképp ellehetetlenítették a kisiparosok múködését, a kisipari szövetkezet tizennyolc alapító tagja közül tizenegy volt a suszterek ill. cipöfelsőrészkészítők, hat a férfi és női szabók száma, csupán egy lakatos csatlakozott hozzájuk. A solymári KTSZ, melynek taglétszáma és tevékenységi köre fokozatosan bỏvült, 1955-ben közgyülési dőntés nyomán kettévált; a Vegyes Ktsz tőbbszöri átalakuláson átesve, kiválások során keresztül, ám a kilencvenes évekig folyamatosan tevékenykedett, a Solymári MưanyagJátékáru és Tömegcikkipari Ktsz, amely a falukőzpontban és a babagyártáshoz fôlhasznált gyúlékony cellulóz miatt a falun kívuili telepen - a majdani PEMÜ telephelyén - múkődött, értékesítési nehézségek, veszteséges gazdálkodás miatt négy év múlva fölszámolásra került ${ }^{24}$. Az 1959-ben megalapított PEMÜ ugyan nem tekinthető a ktsz jogutódjának, a megyei Tanács új vállalata mégis a kisszővetkezeti vagyonnal és annak régi dolgozóival, 195 emberrel kezdte meg múködését. Ez a körülmény, a "ktsz-es múlt" s az, hogy a PEMÜ megyei tanácsi alapítású cég volt, amely fölött a minisztérium csak szakmai felügyelettel rendelkezett, a vállalat magára utaltságát eredményezte; ebben az üzemben nagyon sok mindent, épủletet, gépet $\mathrm{s}$ késóbb szociális létesítményeket, az óvodát, rendelöintézetet az itt dolgozóknak kellett, többnyire társadalmi munkában létrehozniuk. A vállalat törzstagjai valóban úgy érezhették, maguk teremtették meg a gyárat; "az idősebbek gyakran emlegetik a bizonyos pemús szivet, volt valami plusz, ami az embereket a pénzen fölül motiválta", mondja az 1993-ban privatizált PEMÜ RT elnökvezérigazgatója, aki lényegében 1960 óta dolgozik a vállalatnál, hisz vegyészeti főiskolai és egyetemi tanulmányait a PEMƯ társadalmi ösztöndíjasaként végezte el. A PEMÜ mindig is támogatta dolgozói szakmai továbbfejlódését, képzett szakembereket csábított Solymárra; a cég jelenlegi menedzsmentje húsz-harminc éve dolgozik együtt. "Büszkeséggel vagy anélkül egyértelmũen meg lehet állapítani, hogy Solymáron szorgalmas emberek élnek, és ezt nem feltétlenül kapcsolnám össze a svábsággal, itt mindig jó kollektiva volt, hisz az emberek ismerték egymást", vélekedik a vezérigazgató. Annyi bizonyos, hogy a PEMÜ Solymár életében játszott meghatározó szerepének egyik fontos mozzanata, hogy maga is hozzájárult a kitelepítés után megfogyatkozott lélekszámú svábság és a betelepített, betelepült emberek kőzőtti merev bizalmatlanság feloldásához. 
A PEMÜ mondhatni eminens vállalatnak számított, $s$ bizonyos értelemben számít ma is. A magára utaltság nagyobb mozgásteret is jelentett; a tervgazdaság idöszakában ipari müanyagtermékek gyártására specializálódott vállalat alapanyagés gépimportra szorult, kezdettől nagy volt az igény a nyugati cégekkel való rendszeres kapcsolattartásra. Abban, hogy a legmeghatározóbb uizleti partnereket Nyugat-Németországban találták meg, nem elhanyagolható szerep jutott a PEMỨ sváb származású, németủl vagy éppen a dialektust jól beszéló szakembereinek, " $a$ PEMÜ termelésének egynegyedét exportálja, és a nyugati partnerek jó néven veszik, hogy nincs kommunikációs gond, a gépleirásokat, rajzokat sem kell lefordítani a szakmunkásoknak, mert azok is tudnak beszélni". A korán kibontakozott ilyugati kapcsolatoknak kőszőnhetően játszott a PEMÜ úttőrő̉ szerepet a közős vállalatok alakításában; 1984-ben itt hívták életre az első termelö típusú vegyesvállalatot az országban, a KEMIPURT, német közremükődőkkel. A nyolcvanas évek folyamán sorra alakuló vegyes tulajdonban lévő vállalkozások a kilencvenes évek által kikényszeritett változ(tat)ások idején jelentös mértékben hozzájárultak a cég talponmaradásához, részint, mert a munkaerỏ racionalizálása során át tudták venni az emberek egy részét, részint, mert stabil piaci kapcsolatokkal rendelkező, kapitalista üzemekként mükodtek, melyekre nem nehezedett sem az adósság, sem a privatizáció terhe.

A solymári kơzpontú PEMŨ az évtizedek folyamán hatalmas, a hetvenesnyolcvanas években 2700 embert foglalkoztató uzemmé nötte ki magát; a megyei vezetés ugyanis rendre hozzácsapta termelési, likviditási nehézségekkel kuszzkődő vállalatait. Jelentơs telephelyek alakultak ki elsősorban Zsámbékon és Cegléden ${ }^{25}$, ahol a központnak meglehetös sok pénzt és munkát kellett invesztálnia az eredményes mükődés érdekében. A zsámbéki uzem kivételével, ahol a privatizáció során a PEMÜ-nek el kellett adnia vagyonrészét a korábban alapított vegyes vállalat nyugati tulajdonosának, a PEMÜ ma is egyben áll, csak éppen, sokadszori átszervezés és a privatizáció után. A PEMỨ RT ma kvázi-holdinként mükődik, az ơt telephely divízióvá szerveződőtt - önállóan gazdálkodnak, de jogi értelemben véve nem önálló gazdasági személyiségek -, mellettük tevékenykedik a 11 vegyes tulajdonú Kft (Solymáron három), amelyekben a PEMÜ részesedése 10 és 70\% kőzơtt mozog, valamint a teljesen a részvénytársaság tulajdonában lévő exportimport leányvállalat.

A rendszerváltás időszaka mindenekelött átmeneti piacvesztést jelentett a vállalatnak, a cipőipar válsága visszavetette a cipó-alkatrészek gyártását, a zsámbéki üzem elvesztése egyúttal a mủanyag csővek piacának elvesztését is jelentette. Néhány év alatt azonban sikerult a piaci kapcsolatokat átrendezni, a kiesett termékeket újabbakkal kompenzálni, a PEMÜ-nek ma az autógyárak, pl. a Suzuki fontos megrendelöi, és a piaci egyensúly helyreállitásának kơszönhetően az árbevétel visszaesése után az idén már számolnak a nyolcvanas évek végi árbevételi szint elérésével. Nehezítette a vállalat helyzetét az a tény, hogy 1987 és 1990 között kétmilliárdos világbanki hitellel jelentős géppark-modernizálást hajtottak végre a PEMỮ-ben, melynek hosszú távú jótékony hatására egyelöre árnyékot vet a hitel törlesztésének feladata. Mindekőzben, 1993-ban kiírták a PEMÜ privatizációs pályázatát, amelyen nyolcan indultak, $s$ melyet a PEMÜ (akkor) Kft és az MRP kőzős pályázata nyert el. Ma a PEMÚ vagyonának $65 \%$-a van az MRP, a dolgozók 
kezében, 6\%-on osztoznak az érintett ơnkormányzatok, $29 \%$ az RT tulajdona. A tulajdonból való részesedés mértékének meghatározásakor elsősorban a nettó kereseteket veszik figyelembe, de a PEMÜ-ben eltőltơttt évek száma módosíthatja azt, s egy elkülönitett részt arra tartanak fenn, hogy a beinduljon a belső részvényforgalom. Egyelöre senki nem vásárolt részvényeket. Abban, hogy a gyár menedzsmentje az MRP-konstrukcióban pályázott a privatizációra, az ùzem elsó emberének meggyóződése nagy súllyal nyomott a latban.

$\mathrm{Az}$ elnők-vezérigazgató solymári sváb kocsmáros-családban szuletett, az apát kuláknak minösítették, minden tulajdonukat elveszítették. "A munka mindenek fölött áll, mindent megelöz" és "a kicsi, apró dolgoknak is örülni kell"; ezt hozta hazulról tanításként, és a tanulmányai során kulák-gyerekként szerzett tapasztalatot, "tudtuk, hogy a jók között is legjobbnak kell lenni". 1990-ben a vállalati tanács kérte fôl arra, hogy adja be pályázatát a vezérigazgatói posztra, melyet tizenegy induló kơzül nyolcvan százalékot meghaladó szavazati aránnyal nyert el. Az amerikai vállalati példa tanulmányozása mellett ez a magas támogatottság is arra indította, hogy a munkavállalói részvényprogram mellett tegye le a voksát; "erkölcsi kötelességemnek tartottam, hogy a gyár azoké legyen, akik itt dolgoznak, hogy ebben a kérdésben nem lehetek önzö, hisz a privatizáció során minden lehetỏség megvolt arra, hogy a menedzsment visszaéljen a helyzetével, és biztam abban is, hisz nagyon sok kollégával együtt nốttem fel, hogy a tulajdonlásból fakadó kötelezettségeket is átveszik majd." A privatizáció sikereként értékeli azt a tényt, hogy a PEMÜ magyar cég maradt, az is akar maradni, és azt, hogy minden szakértó hangsúlyozza, a PEMÜ azon kevés MRP-s cégek közé tartozik, ahol a menedzsment korrektül viselkedik, nem saját tulajdoni részének növelésére tơrekszik. Ám minden dicséret csak addig érvényes, amíg a vállalat eredményesen mükődik. $S$ ha itt ठsszehasonlításokat kell tenni, akkor bizony a közös vállalatoknál a betegállományban eltőltött napok aránya 4, a PEMÜ-ben viszont 10\%, holott "a saját tulajdonából" megy el $\mathrm{el}^{26}$, a vegyes vállalkozásokban jobban félnek az emberek, hogy elveszitik munkájukat. Igaz, jobban is keresnek, de a PEMÜ dolgozói még vagy egyhavi fizetést megkapnak a megmaradt szociális, jóléti ellátáson (egészségügy, üdülés, sport stb.) keresztül. Be kell hảt látni, hogy ez a konstrukció "nem igazán kapitalista, nem igazán piacszerü - de vállalni kellett".

A tulajdonlásból fakadó jogok $\mathrm{s}$ fóként kőtelességek tudatosítása azért is nehézségekbe ủtkőzik, mert 2002-ig a gyár tulajdonosai évente százmilliót kőltenek arra, hogy a gyárat megvegyék az államtól. Az MRP szervezet a megkapott E-hitelt törleszti még ôt évig, $s$ addig évente a tơrlesztés fuggvényében kerül a már fölszabadult rész fölosztásra a tulajdonosok kőzött, ez a tulajdon így még csak elvi tulajdon. Ám addig is, amíg a tulajdon valódi tulajdon lesz, a menedzsment, "és ebben is úttörök vagyunk", a Magyar Részvétel Alapitvány közremükődésével és az amerikai fejlesztési intézet támogatásával megindította a MÁS (az MRP Átalakítása a Sikerért) programot, amelynek középpontjában a tulajdonosok képzése áll, a folyamatos kommunikáció, annak tudatosítása, hogy mit jelent a tulajdon, hogy a tulajdonos alapvető érdeke mindenekelött az, hogy a vállalat sikeres legyen, mert siker, gazdasági eredményesség nélkül a tulajdon is értelmét és értékét veszti. 
Kétségtelen, hogy számos bizonytalanság és probléma merül fel az MRP konstrukcióval bssszefüggésben, $s$ nem csupán rövid távon, amikor a hiteltörlesztés és a tulajdon kiváltása kimerítik a vállalat kapacitásait, $s$ a tulajdonos dolgozók a kơzös sikerre való ösztơnzzést vagy épp annak hiányát a béreken keresztül érzik csak. A program sikerét a piacgazdasági környezet is veszélyezteti, és nem tudni, az esetleges cserék a gyár vezetésében milyen mértékben hangolják majd át a jővőben a menedzsment tulajdonhoz való viszonyát. Mindezek bizonytalansági tényezők, amelyek odabiggyesztik a kérdőjelet a sikertörténet végére. Ennek ellenére siker az üzem fennmaradása, az a tény, hogy drámai mértékủ, szervezett leépítésre egyedül Zsámbékon kényszerult a menedzsment, és siker a dolgozók tulajdonhoz juttatása; 240 solymári dolgozó egyben MRP-tag is. Siker végül az is, hogy a kơzség életével oly sok szálon összefonódott legnagyobb solymári vállalat átalakitása úgy zajlott le, hogy nem rendítette meg a helyi gazdaság és társadalom alapjait, a feladat, amelyen a menedzsmentnek úrrá kellett lennie, egy üzem problémája maradt, nem lett egy egész település válsága.

\section{"A hagyomámyok nélkül elszürkülünk"}

A helyi gazdaság differenciáltsága és ereje, úgy vélem, Solymár sikerének egyik forrása. A gazdaság szférájában eltünnek azok a különbð̋zőségek, amelyek határait az azonos származás, közőss tradíció, egyező identitás jelöli ki. A kőzség életének más szféráiban, mindenekelött a hagyományos és önszerveződő kőzősségek, a kultúra, az oktatás terủletén jelentöségùk azonban megnó. Már említettem, hogy Solymár kulturális, közösségi életét jelentơs mértékben a német kisebbség formálta $\mathrm{s}$ formálja $\mathrm{ma}$ is. A kulturális hagyomány ebben a faluban lényegében a kisebbségi pozícióban lévő svábok kultúrájának ápolását jelenti, lényegében, de nem kizárólagosan. Solymár kőzösségi élete elválaszthatatlan attól a gazdag zenei kultúrától, amelynek forrásvidékét a híres solymári sramli-zenekarok és az eleven dalkultúra tájékán kell keresnünk, ám amelynek újjáleszztése a valamilyen útonmódon Solymárra kerult megszállott zenepedagógusok teljesítménye volt. Egyáltalán, "Solymárnak nagy szerencséje volt", mert olyan embereket vetett ide a tơrrténelem szeszélye, illetve olyan emberek választották Solymárt otthonuknak, akik hozzájárultak ahhoz, hogy a kitelepítés után a megfélemlített, sok tekintetben megnémult közösség ismét fơlfedezze, és vállalni merje saját értékeit.

1946 tavaszáig Solymár nemzetiségében és vallásában homogén község volt. Ennek nem mond ellent az a tény, hogy a faluban élö német nemzetiségi lakosok körében igen erös volt a magyar nemzettel szembeni lojalitás és az asszimilációs igény, melynek számos jelét is adták. A múlt század végén a német tannyelvü egyházi elemi iskola megszüntetése és magyar kőzségi elemi iskola létrehozása mellett döntött az előljáróság, a harmincas években a falu vezetése és a szülők együttes fellépésének köszönhetỏen sikerült visszaállítani a magyar tannyelvü, a németet kevés óraszámban tanító, ún. C-iskolatípust a községben, mert úgy látták, gyermekeik jövơjét veszélyeztetné a tiszta német tannyelvü oktatásra való áttérés ${ }^{27}$. A harmincas években, ha csak 23 taggal is, müködött Solymáron a Jakob Bleyerféle Német Népmủvelődési Egyesület, az asszimilálódásnak gátat vetni akaró, a nagynémet törekvésekkel nem szimpatizáló, mérsékelt szervezet helyi csoportja ${ }^{28}$. 
E tömörülés eszmei hatása nyilvánvalóan szélesebb körben éreztette hatását, hisz vezetője Hufnagel Ferenc volt, aki 1917-től 1946-ig a kőség plébánosaként múkődött, ám az 1938-ban megalakult, német támogatást élvezó radikális Volksbundnak ebben a faluban nem sikerült gyökeret vernie, 1944 végén a szervezetnek csak 160 tagja volt. Tény, hogy a harmincas évek honi újságjaiban Solymár neve, hol az oktatásủgyben megjelent változtatási törekvések, hol a községben fölbukkanó német agitátorok elleni tiltakozással összefuiggésben, fölfolbukkant, a magyar sajtó örömére, a német kisebbség sajtójának megbotránkozására.

1941-ben a községben 4.096 lélek élt, közülük 3.397 magyar, 695 német nemzetiségünek, 1.636 magyar, 2.446 német anyanyelvünek vallotta magát. "Ebben a községben, úgy látszik, jelentékeny számú magyar érzésũ sváb él", írta 1941-ben a Statisztikai Hivatal elnöke egy a Teleki Pál számára készített bizalmas jelentésben ${ }^{29}$, és igaza volt akkor, amikor úgy látta, hogy azokon a településeken, ahol sem magyar, sem német propaganda nem befolyásolta az embereket, az "anyanyelve" kérdésre adott válaszukban a valós nyelvhasználati viszonyokról adtak számot, míg "nemzetiségiként" inkább a magyar állam és haza iránti lojalitásukat fejezték ki. Úgy tưnik azonban, hogy a helyzet ennél is kuszább volt; visszaemlékezésekből kitưnik, hogy az 1941-es népszámlálás nemzetiségi, nyelvhasználati kérdéseire adott válaszokat számos tényezó befolyásolta, mint mondjuk egy-egy tanult, kðztisztviselóként dolgozó rokon ${ }^{30}$ súgása, jóval inkább azonban a számlálóbiztos beállítottsága, elkötelezettsége. A kérdezö nem fơltétlenül vette figyelembe a tényleges viszonyokat, s még mielőtt a kérdezett megszólalt volna, beírta az általa helyesnek vagy a kérdezett szempontjából hasznosnak ítélt választ. Ennek eredménye volt öt esztendővel később, hogy a kitelepítés során egész utcák kiürültek, máshonnan viszont egyetlen embert sem vittek el.

1946. április 18-án és 23-án ơsszesen 1.960 embert telepítettek ki Solymárról. Voltak, akik, ha kellett háromszor is nekiindultak, hogy hazatérjenek, ók azután a faluban rejtőzködve félték a jơvőt. Lassan megjöttek az elsó levelek "kintrôl haza", az itthon maradottak levelei azonban eleinte nem érkeztek meg a címzettekhez, az ötvenes évek végén azután megindultak a kölcsönös látogatások. Itthon a további kitelepítésektől való félelem sok családot névmagyarosításra késztetett, a falura "halotti némaság" telepedett, "amikor 1941-ben idekerültünk Solymárra, már az állomástól lehetett hallani, ahogy a Templom téri kocsmában énekelnek a férfiak", emlékezik az énektanárnő, a kitelepítéssel megszünt a férfikórus is, csak az egyik zenekar szerveződőtt újjá, ott két nem sváb ember is játszott már. Marosvásárhelyről három évi burgenlandi tartózlłodús után vetởdött Solymárra egyikuk, hozta magával harmonikáját is. Udvarolgatott a sváb vendéglős lányának, de hiába, hisz jöttmentnek számított, "aztán, hogy a zenekarban játszottam, megismertek és megszerettek." Ennek ellenére kisebbfajta botrány kerekedett abból, hogy nővérét éppen egy sváb család orvos fia vette feleséguil. A kitelepítettek helyére érkezett mezőkövesdi summáscsaládokkal, felvidéki magyarokkal jó egy évtizedig fagyos és mereven elutasító volt a viszony, a lassan olvadó légkörben nem pusztán vegyes házasságokra került sor, az idő is "helyrezökkent" az első tanácsválasztásoknál, ekkor a tanácstagok fele sváb lett, a kiegyensúlyozott arányok végig megmaradtak. "Solymárnak szerencséje volt, itt a községi meg a pártvezetés józan volt, nem voltak elvadult kommunisták", vélekedik a község volt, sváb 
családból származó vb-titkára, aki több mint harminc évig, lényegében a rendszerváltásig töltötte be fontos tisztét, miközben tanácselnökök, párttitkárok jöttek-mentek. Fokozatosan, a Hazafias Népfront védőszárnyai alatt föltámadtak a közösségek, a Solymári Férfikórust 1968-ban a vb-titkár, egy sváb származású Kossuth-dijas öntömunkás, és a HNF titkára, a Felvidékröl harmincas években áttelepült katolikus újságszerkesztő iniciálták, az 1970-ben megalakult Helytörténeti Társaságban mellettiuk Solymáron élő régész, történész tanár is megjelent. A Társaság tudós tagjainak sokat köszönhet a falu: régészeti leleteket, tanulmányokat, a solymári várhegy feltárását, az 1972-ben megnyitott Helytörténeti Múzeumot. Az. a tudás, ismeretanyag, melyeket ők fölhalmoztak és közkinccsé tettek, hozzájárult ahhoz, hogy török uralom alatt elpusztásodott és sváb telepesekkel újra benépesített falu 1966-ban 700 éves múltját saját múltjaként ünnepelje. Megszületett Solymár címere is, melyen a solymári történelem különbözö rétegeire utaló jelek kerültek egymás mellé; háttérben a középkori vár, elötérben a magas dombon a királyi solymász, karján a nemes madárral, jobboldalt a sváb telepesekre utaló szölővesszö. (A kilencvenes évtized elején, a községi jelképek rögzítésének idején egy grafikusmüvész új, a heraldikai elvárásoknak megfelelőbb címert tervezett, ám a solymáriak hevesen ragaszkodtak a megszokott régihez.)

"Az énektanárnó nélkül Solymáron nem virulna ilyen gazdagon a zenei élet". A nyugat-dunántúli polgári származású asszony férjével, egy volt katonatiszttel 1941-ben érkezett Solymárra. Az ötvenes és hatvanas években, egészen a községi zeneiskolai tagozat megalakulásáig, egy kolléganőjével együtt magán zeneiskolát tartott fenn, az általános iskolában megkezdte a kórusmunkát, zenét szeretó generációk sorát nevelte fơl a faluban. A törékeny, mélyen vallásos asszonyt az óslakosok bizalmukba és szeretetükbe fogadták, mikor férje az ötvenes években börtönbe kerültt, a templomi perselyben megcímzett borítékban pénzt, tanitványok szüleitöl és névtelen segítóktől élelmet, ruhát kapott. Akkor is járt a solymári templomba, amikor kollégái, az erősen baloldali elkötelezettségü igazgatónőtől félve, Máriaremetére mentek vasárnaponként, és az általa vezetett felnőtt kórusoktól nem várták el, hogy mozgalmi dalokat énekeljenek, a Férfikar legfeljebb a Marseillaise-t adta elö Kodály földolgozásában. 1971-ben a müvelődési ház zeneakadémiát végzett akkori igazgatónöje hívta fól figyelmét egy idősebb asszonyokból álló társaságra, akik, valamelyikük névnapját ünnepelve, a cukrászdában énekelgettek. Ezek az asszonyok gyermekkoruk óta ismerték egymást, a téeszben, temetéseken együtt énekeltek, rengeteg régi dalt ismertek. $\mathrm{Az}$ énektanárnő ezekkel a kottát nem ismerő asszonyokkal szervezte meg a híres Solymári Hagyományőrző Asszonykórust, nem ment könnyen, mert az asszonyok a rádióban hallott német dalfeldolgozásokat tartották "szép énekeknek", azokért rajongtak, s visszalépésnek tartották saját népdalaik éneklését. Ezek a népdalok azután, 27 évi közös munka és gyưjtés után megjelentek 1995-ben. Solymár jelenleg mükődő négy felnőtt kórusa közül, jellegéből fakadóan, csak az Asszonykórus áll kizárólag sváb származásúakból, minden más énekkarban vegyes összetételü a tagság, és döntően klasszikus a repertoár. Különösen a legrégebben alakult Férfikar tagjává válni jelentett egyben utat a betelepültek számára az őslakosok közösségéhez, ez az a társaság, amely kialakította saját társas szokásait, hagyományait, rendszeresen megvendégelik Pünkösd hétfö délutánján Solymár zeneszerető lakosait. 
Solymár iskolájában a nyolcvanas években volt már emelt óraszámú nemzetiségi oktatás, 1991-ben vágtak bele a kéttannyelvủ képzésbe, az óvodai nevelésben is helyet kapott a német nyelv. Solymáron lényegében minden gyerek kiskorától tanulja a német nyelvet, legyenek ősei svábok vagy "stockmagyarok", a kéttannyelvủ oktatás keretén belul kötelezó néptánc-foglalkozásokon pedig fơként sváb táncokat tanulnak meg a gyermekek. A nemzetiségi hagyományok megjelenése a helyi oktatási struktúrában mindenekelőtt azt jelenti a betelepült tỏbbség számára, hogy a gyermekek magas színvonalú nyelvi képzésben részesủlnek, ugyanakkor az óvódán, iskolán keresztull kőzelebb kerủlnek egymáshoz "őslakosok" és betelepulltek; azokon a községi rendezvényeken, ahol a gyerekek follépnek, márpedig majd mindig fóllépnek, a szülök, nagyszülők is megjelennek. A sváb tradíciokkal való érintkezés az iskolában, az ifjúsági tánccsoportban a befogadás és a beilleszkedés érzését ébresztheti fỏl az érintettekben; "öt éve költözött ide az egyik barátom, az ố fia táncol, és rém büszke rá, hogy solymári barátai vannak". Az ifjúsági tánccsoportot és az iskolai táncoktatást egy már nyugdijjas korban lévő pedagógusnó irányítja, aki ugyancsak a negyvenes években került a községbe, itt egy helybéli kereskedő család tisztviselö fia vette feleségủl. A rendkívül energikus asszony vezeti a solymári nyugdíjas klubot is, ahol egyensúlyoznia kell, hisz néha fölfortyannak a felvidékiek, ha társaik svábozni kezdenek, "de az öregek között a helyiek vannak többségben, a svábok birják még hangerōvel". Ök alkotják a katolikus képviselőtestület kétharmadát is, ami persze nem jelenti azt, hogy a német misézés magától értetődő volt vagy lenne a községben. A Heimatverein-Falukör elsó dolga volt 1991-ben egy német imakönyv kiadása, a vasárnapi tízes misén a hívek németủl énekelték a dalokat, németull prédikálni azonban nem volt hajlandó a község akkori plébánosa, erre, havi egy alkalommal, és egyelöre próbaképpen 1997 őszétól vállalkozik a katolikus hívek új, fiatal pásztora.

"Ebben a községben a hagyományok fontosak, azért is akarják megtartani öket, mert a hagyomány megtartó erón", vélekedik a református egyház presbitere, aki visszaemlékezve hajdani zenész éveire, állítja, "mikor játszottunk, zsúfolva volt minden, a zene által is közel lehet kerülni az emberekhez." Sikeres koncertek rendezésével a református egyház is zỏkkenỏk nélkül kapcsolódott a helyi tradíciók zenei áramához, és a nyolcvanas években idekerült lelkészcsaládnak kőszőnhetően, a solymári közösségi élet egyenrangú és megbecsült tagja lett. "Az maga volt a csoda", amit az azóta elhunyt lelkész Solymáron elvégzett. A néhai nagytiszteletü úr feleségével egyưtt üzletkötőként dolgozott - élete egy szakaszában színész is volt -, amikor ötvenöt évesen nekifogott teológiai tanulmányainak, és hatvan is elmúlt, amikor elsó, s egyben utolsó szolgálati helyére érkezett. Itt egy düledező, vályogból épưlt imaházat és vagy tizennyolc templomjáró reformátust talált, halálakor egy adományokból és a hivek Isten dicsőségére végzett, ingyenes munkájából fỏlépített templomot és egy hétszáz tagot számláló gyưlekezetet hagyott utódjára. Presbiterekkel egyưtt járta végig többször is a családokat, elvarázsolta őket hitével, lelkesedésével és szótehetségével, felesége a gyerekek nyelvét ismerte és beszélte; egyre tỏbben jártak hitoktatásra a régebben vagy újabban betelepült református családok gyermekei kỏzủl. Tủl azon, hogy kovászként tartotta egyben hittestvéreinek közỏsségét, a tágabb solymári környezethez is sikerrel igazodott, tudta, hogy "itt nekünk kell alkalmazkodni, itt elvárják, hogy a református lelkész, a 
presbitérium tagjai részt vegyenek a községi összejöveteleken, és a lelkész úr elment mindenhová, kaptunk is sok támogatást az önkormånyzattól" és a templom építésekor a tanácstól, a nem református lakosságtól is, "mert a munkának, a szorgalomnak itt nagy becsülete van", és a közösség értékeli a tradíciókhoz, így a hithez való ragaszkodást is. "A mi községi ünnepeink a templomban kezdödnek és ott végződnek, megpróbáljuk az embereket a templom felé terelni", mondja Solymár polgármestere.

A presbiter azok kőzé tartozik, akik teljes lojalitással fordulnak az öslakosok közösségei és hagyományápoló tevékenysége felé, részt vesz a falu "szuper" ünnepein, ơ még ahhoz a generációhoz tartozik, amelynek tagjai, legyenek bármilyen származásúak, ismerik és az utcán köszöntik egymást. A növekvó lélekszámú Solymáron élnek olyan polgárok, akik számára szủkős a tradíciók által nyújtott cselekvési keret, akik újabb értékek meggyökereztetésért lépnek a helyi közélet porondjára, ahogy olyanok is, akik nem elégszenek meg az oktatási intézmények, kulturális egyesületek kínálatával. "A solymáriak egyszerre zártak és nagyon nyitottak", ez a kettősség megtermékenyitő, ennek és az emberek igényességének köszönhetỏ az elmúlt években egy új vegyeskórus alakítása, a magyar gyermek-tánccsoport megszervezése a müvelódési házban, a kéttannyelvü és nemzetiségi oktatás mellett az angol tagozat beindítása az idén kezdő elsösök kőzőtt. Solymáron hívták életre a lelkes szülök, egész Kelet-Európában elsőként, a Waldorf óvodát, azóta egy falusi iskolájuk és fơiskolájuk müködik itt. Jellemzó azonban, hogy az alapítók között csak egy sváb származású asszony bukkant föl, s akkor is, ha az oktatási intézmények és a Waldorf szellemisége iránt az alapitás óta eltelt majd egy évtizedben megnött az érdeklödés, jellemzöen nem a törzsőkős sváb társadalom tagjai közül kerülnek ki az új, alternatív értékek legelkötelezettebb szószólói és harcosai. A negyvenvalahány tagot számláló Környezetvédök Egyesületének vezetőségében is meghatározó szerephez jutnak azok az asszonyok, akik az elmúlt években költöztek a községbe, elnöknőjük egy már a háború előtt a községben élö és praktizáló orvos kertészmérnök gyermeke, az aktív tagok javarésze a fơvárosban dolgozó értelmiségi. Noha a környezetvédök által képviselt értékek, akárcsak másutt e honban, nehézkesen tudják áttörni a kényelem vagy a közöny korlátait, Solymáron sikereket is számon tarthatnak; eredményesen léptek fơl a külterưleten fekvő téglagyár légszennyezése ügyében, fórumot szerveztek az M0-ás kőrgyürủ tervezett útvonaláról, ahol annak szlikségtelen és környezeti károkat okozó mivoltára hívták fel a jelenlévők tőbbségét meggyőzve a figyelmet, Diána-Napot, a Föld-Napján az általános iskolában elöadásokat tartottak, megkezdték a szelektiv hulladékgyuijtést a nagyközség több pontján, stb. Erđôtakaritási és faültetési akcióiban az iskola, több vállalkozó és mindenekelött az önkormányzat is részt vesz. Egyik legfontosabb eredményửk talán éppen az a tény, hogy a község képviselötestülete nem afféle habókos zöldeknek, hanem partnernek tekinti őket, $\mathrm{s}$ ennek nem csak az általuk szervezett akciókban való részvétel révén adják kifejezését, hanem abban is, hogy a községi környezetvédelmi rendelet kidolgozására meginvitálták az egyesületet. A solymári siker egyik összetevőjének nevezhetném, és mindenképpen értéknek tartom, hogy a község vezetése igyekszik egyensúlyt teremteni a tradíció és az új értékek, az őslakosok és a folyamatosan beköltőzök között. 
1994-ben az önkormányzati választások elött vagy húsz ember fogott össze, hogy az "Így ne tovább!" jelszava mögé fôlsorakozva, pártoktól független választási koalíciót alkosson, kezdeményezöi az akkori polgármester vezetési és munkastilusával elégedetlen képviselök ill. választópolgárok voltak. E választási csoporttal - amely a jelenlegi 14 fós testületben, a polgármesterrel bezárólag tíz pozíciót tudott megszerezni - szorosan együttmúködtek a német kisebbségi onkormányzat ugyancsak megválasztott tisztségviselői. Kezdettől határozottan az az álláspont alakult ki a csoporton belül, hogy váljék ketté a települési és a kisebbségi önkormányzat, noha a települési önkormányzati jelöltek zöme a származási közösséghez tartozott, ők, egy kivétellel ${ }^{31}$, nem nemzetiségi színekben óhajtottak indulni. A jelenlegi testület tíz tagja sváb családban született, sokan "sváb testület"nek is nevezik, ám egyrészt nem mindegyik képviselö tartja fontosnak és firtatandónak a maga és mások származását ${ }^{32}$, másrészt mindenki tisztában van azzal, hogy a településen, ahol a lakosoknak negyede ${ }^{33}$ tartozik származás szerint a német kisebbséghez, "nem lehet túldimenzionálni a testületben a sváb ügyeket". A kisebbségi önkormányzat pedig úgy látja, hogy a testületi üléseken olyan kérdésekben döntenek, amelyek többnyire közömbösek nemzetiségi szempontból. A kisebbségi önkormányzat az oktatás és kultúra területén élhet véleményezési jogával, alapvető feladatának a kisebbségi hagyományok örzését, megtartását, az identitás megerösitését tartja. Solymár község kulturális életében a kisebbségi önkormányzat pusztán legitim közhatalmi léte, és mégoly korlátozott jogosítványai révén új és nagyobb hangsúlyt ad a sváb tradícióknak; a kisebbségi önkormányzat elnöke talán nemzetiségi egyesületek vezetőinél nagyobb eredménnyel tárgyal, veszekszik plébánossal német miséért, testületi tagokkal a kéttannyelvủ oktatás további támogatásáért, mert püspökhöz, ombudsmanhoz fordulhat, vétójogot gyakorolhat. Minderre még nem került sor, Solymáron a kisebbségi önkormányzat a községvezetés teljes erkölcsi és lehetőség szerint anyagi támogatását élvezi, ennek azonban alapvetö feltétele a testületek illetékességi körének, müködési területének elválasztása.

\section{Ünnepek, ritusok egyensúlya}

1996 Solymár életében a megemlékezések és új, hagyományt teremtő ünnepek éve volt, s a közơsség összetartozását, identitását megerösító események során meghatározó motívumként, a szervezök, résztvevök, a községvezetés szándékaként húzódott végig az értékek, a lakosság különbözö csoportjai közötti egyensúly megteremtésére, megerősítésére való törekvés.

A helyi ünnepek sorában a millecentenárium bírt a legkevesebb jelentőséggel, iskolai és községi megemlékezések, történelmi "ki mit tud"-ok mellett a képviselötestulet uunnepi ulésén elfogadott, és a helyi sajtóban "Hittel és felelösen"134 címmel közreadott nyilatkozat tekinthetö érdemleges eseménynek, amely a község életét, ünnepeit és rítusait nem alakítja ugyan, de kétségtelenül szimbolikus gesztusnak tekinthetö. Ebben a nyilatkozatban a község nemzetiségi történelme és mivolta nem kerül említésre, a testület tagjai, illetve a szöveg írója - a nyolcvanas évektôl a faluban élő és tanító történelemtanár, polgármester-helyettes - pátoszos hangvétellel emlékeznek meg a nemzeti történelemről, jelezve, hogy a "nehéz sorsú nép" szenvedései - tatár és török uralom, "a trianoni tragédia" és a ránktelepedő 
"nagy vörös keleti birodalom" - egyben a solymári közösség szenvedései is. "Mindezeket tủlélte a nemzet: köszönhette ezt az Istennek, kiemelkedö fiai áldozatának, fel-felbukkanó pozitív tulajdonságainak. De hatalmas árat fizettünk; az ösi fold egy része elveszett - a vér felhigult - a lélek kihúlt - a nemzeti karakter eltorzult - Istent elvesztettük!" A nemzet elött álló feladat nem kevés, egy "életképes és igazságos társadalom" építése, az emberek hitének, optimizmusának, szilárd erkölcsi értékrendjének és a nemzettudatnak, valamint a határokon túli magyarság pusztulásának megállítása. Mit tehetnek mindezért a solymáriak? "Látszólag keveset, de ha a szervezet egy parányi része visszanyeri erejét, az egész test egészségesebbé válhat." A testület mindenkit megszólít, ơnmagát, az egyesủleteket, pártokat, a pedagógusokat és a családokat, tegyenek meg mindent a kőzélet iránti kőzőny megszüntetésére, nyissanak az ifjúság felé, neveljenek testben-lélekben egészséges gyerekeket, ne csak anyagiakat, hanem szeretetet is nyújtsanak gyermekeiknek, alakítsanak ki a következó generációban "szilárd erkölcsi rendet, hagyománytiszteletet és magyarságtudatot". "Kérjük Isten segítségét községünk felvirágzásához és a magyar nemzet további ezeréves egészséges fejlődéséhez...", zárul az ünnepi nyilatkozat.

"Üdvözítōnk amyja Mária/hálatelt szívvel köszönik/pártfogásodat a kitelepítettek és az itthon maradottak,/akik a nehéz években is biztak /oltalmadban. Hírdesse ez $a z$ emlékmü/a megbocsájtást és az egymás irántil szeretetünket. Szolgáljon mementoként a jelenkor/ és a jövő nemzedékei számára örök/tanulságul. " 1996 a magyarországi németek kitelepítésére való megemlékezés éve volt Solymáron is. A községben a kétnyelvü felirattal ellátott márvány-bronz emlékmü, a többnapos, kiállítással, koncertekkel egybekötơtt májusi megemlékezési ünnepség kőltségeit az egyház, az ơnkormányzat, a helyi lakosok és fóként a kitelepítettek adományaiból fedezték. A Hỏsök Napján a kegytemplom nyugati falán német nyelvủ mise keretében felavatott és megszentelt kitelepítési emlékmú "Solymár csillagát", a Segítő Szủzanyát ábrázolja, akinek kőntőse oltalmazóan terül a kitelepítettek szomorú, elcsigázott csoportja köré. Annak idején, mielőtt a vagonokhoz indultak, a templomban utolsó misére gyültek össze az emberek. Megrendítő egyházi és kỏzségi ủnnep volt $\mathrm{ez}$, amely azonban nem nélkülözte a politikai jelentést/jelentöséget sem. A sváb szenvedéstơrténet felidézésének, a többség és kisebbség kiengesztelödésnek országos sorozatában a solymári megemlékezés külơnơs megvilágítást kapott, elơzményei és az ünnepi beszédek okán. A május 25-i ünnepséget megelőzó napokban robbant ki a baranyai lehallgatási botrány, a titkosszolgálat lehallgatta volna tơbb kisebbségi vezető telefonjait. A solymári ủnnepségre hivatalos volt Nikolits István a titkosszolgálatokat felügyelỏ tárcanélkủli miniszter, egyben Solymár országgyullési képviselöje, Kerner Lörinc, a Magyarországi Németek Országos Kisebbségi Önkormányzatának elnöke fölvetette, talán nem volna helyes, ha a miniszter részt venne az ủnnepségen. A miniszter eljött, sỏt, "emelt fôvel" állt ott, és az egész magyar kormány nevében megkövette azokat az áldozatokat, akiket nemzetiségi hovatartozásuk miatt meghurcoltak. Kerner Lörinc beszédében az akkortájt napvilágra került 1945-ös kormányülési jegyzökönyveket idézte, melyekből egyértelmüen kiviláglott a magyar kormány felelőssége a németek kitelepítését érintő dőntésben; a hallgatóság tapssal honorálta azt distinkciót, mely szerint nem a magyar nép, hanem az akkori magyar kormányzat büne volt a kitelepités. 
A kitelepitésröl való ünnepélyes megemlékezés egy történelmi időszak, éspedig a hallgatás időszakának lezárását jelentette azáltal, hogy az igazságtalan kollektív büntetés során elszenvedett közösségi és egyéni sérelmeket megnevezte ${ }^{35}$; nagyon kevés volt az a család, ahol erröl egyáltalán beszéltek az emberek, még a hazalátogató rokonokkal is csak elvétve került szóba ez a téma, a nyilvános beszédben a rendszerváltásig lényegében tabunak minósültek a háború utáni események. A kitelepítés a közös szenvedéstörténet megjelenítésével, az emlékmüvel a solymári svábok identitásának elidegeníthetetlen, legsajátabb részévé vált, s egyúttal a község, Solymár identitásának is része lett. 1997-ben a képviselőtestület a hivatalos községi ünnepek sorába emelte a kitelepítés évfordulóját.

A solymári kegytemplom Segító Szüz Máriájához kötődik, évszázados egyházi ünnep a solymári búcsú, amely azonban 1996-ban afféle össznépi, az egész falut megmozgató, kulturális, sporteseményekkel, kirakodóvásárral tarkított, kavalkád, és ugyancsak hivatalos községi ünnep lett. A kitelepítési ünnepség szervezésében oroszlánrész jut a kisebbségi önkormányzatnak, egyesületeknek, de a búcsú elökészítésében és lebonyolításában "visszafogottan" vesznek részt, a többnapos eseménysorozatban csupán egy délután a német és meghívott más nemzetiségeké, a hagyományoké. A szervezőmunka javát a müvelödési ház dolgozói vették magukra, fölkeresték azokat a müvészeket, festőket, színészeket, operaénekeseket, zenészeket, akik Solymáron élnek, meghívták a solymári kézmủveseket és mindenki szivesen jött. A búcsún kiállitó müvészek némelyike jótékonysági árverésre bocsátotta alkotásait, ezzel támogatva a katolikus egyház Golgota Alapítványát, egy új Kálvária kápolnájának és stációinak megépitését. A kiállítást megnyitó író szavai szerint a község "bevonta az új telepesek alkotókedvét is a közösség hagyományai és értékei közé....A jó lokálpatriotizmus és a jó nagyvilágra-nyitottság egyuittélése ez. Mint ahogy az egyik kiállitó mînész, aki Szekszárdon született, a Távol-Keletre, Japánba költözött, hogy tágitsa horizontját, majd japán feleségével és gyermekeivel Solymáron találta meg alkotó munkájához a szép tájat és a jólesổ környezetet - az ugyancsak kiállitó japán müvész pedig hazájából először Indiában kereste, majd végül itt Solymáron találta meg szellemi otthonát. Így nö össze szervesen glóbusz és provincia, egymást kiegészítve." ${ }^{36}$

A kitelepitésröl való megemlékezés a történelem tudatosítása és a következö generációknak szóló intés, üzenet, a búcsú a községben élők közös eröfeszitése, igyekezete, hogy az eltérő kulturális tartalmakat egyenrangú értékként jelenítse meg a nyilvánosság elött, hogy Solymáron óslakosok, idevetettek, új beköltözök a közös ünneplés és mulatság révén mind solymárinak és otthon érezzék magukat, hogy valamennyien itt találják meg az Aranyfalut. A bevezetőben említettem már; az, hogy Solymár sikeres településnek tekinthetö, a különféle tökefajták folyamatos és intenzív jelenlétében gyökerezik, a relatíve autonóm gazdaság, a lakosság vállalkozó kedve és ereje, képzettségi és jövedelmi szintje mellett, azoktól nem függetlenül, az itt élök igényessége és aktivitása is olyan forrást, ha úgy tetszik, tökét jelent, amely nélkul ez a falu nem az lenne, ami: sikeres település. "Solymáron valóban szeretik az emberek a lakóhelyüket, és sokat tesznek is érte." Ilyen egyszerü ez. 


\section{Jegyzetek}

' Írásom címét egy, a Solymári Hímondó 1991. augusztusi számában megjelent cikkből kölcsőnơztem. Nem ismerem azt a mesét, amelyre a Solymár nagykozség agglomerálódásának négy évtizede, a fơváros agressziv terjeszkedése és a hajdani falu visszavonhatatlan átalakulása fơlơtt borongó szerzö hivatkozik, s amely egyfajta profán tékozló fiú - tôrténet; a fiú elmegy, hogy megkeresse az Aranyfalut, melyet végul, hosszú bolyongás után otthonában, szulő́falujában talál meg. Víg Ferenc: 'Aranyfalu'. Solymári Hirmondó 1991.8. Szent György hava. április 20.

2 Tudományos fơmunkatárs, MTA RKK Kozzép - és Észak-magyarországi Tudományos Intézet, Budapest.

${ }^{3}$ 1895-ben 11840, 1935-ben 53489 gyümölcsfát találtak Solymáron az osszeírók. A harmincas évek közepén a Budai Hegyvidék északi részén Solymárt jellemezte a legintenzívebb gyüoulcskertészet. A Magyar Korona orszagainak Mezőgazdasági Statisztikája. 1. rész. A 1895. évi osszeírás fơbb eredményei községeként. MSK XV. kơtet. Magyarország állatállománya, gazdasági gépfelszerelése és gyumollcsfállomannya. 1935. MSK új sorozat 100. kơtet.

${ }^{4}$ Forrás: Az 1930. évi Népszámlálás 2. rész. Foglalkozási adatok kơzségek és kulteruleti lakott helyek szerint, továbbá az ipari és kereskedelmi nagyvállalatok MSK új sorozat 86. kötet.

3 Thirring Alajos: Tájékoztató adatok az iparforgalmi keresónépesség ingavándorlásáról. Magyar Statisztikai Szemle 1935/. 12-22. o.

${ }^{6}$ Az aktiv korá népességben a fơvárosba ingázók aránya 49.7\% volt 1980-ban, 1990-ben magasabb, $60 \%$ volt ugyan, de ez a fơvárosból bekơlttozők nơvekvő számából fakadt, hisz tơbbségük nem adta fol budapesti munkahelyêt. Forrás: Népszámlálás 1980, 1990. Ingázási adatok

${ }^{7}$ 1995-ben az 1000 lakosra jutó vállalkozások vonatkozásában Solymár az élmezỏnyben található (167) a Dunakanyar udulủỏtelepulései, Leányfalu (173), Visegrád (166) valamint Budaörs (168) Szentendre (165) társaságában. Forrás: Az újonnan lehatárolt budapesti agglomeráció fóbb adatai. KSH, 1997.

${ }^{8}$ Seres István: Solymár tơrténete és néprajza. Helytơrténeti Alapítvány 1993. 206. o.

${ }^{9}$ Solymári Hírmondó 1995. június.

${ }^{10}$ A község lakosságszáma 1960: 3615, 1970: 4014, 1980: 5275, 1990: 6209, 1995: 7240. Forrás: Népszámlálási adatok, Pest megyei Statisztikai Évkơnyv.

"Seres István id. mui. 88. o.

${ }^{12}$ Népszámlálás 1990. Pest megye térségeiröli azon belül az agglomerációról két ízben is készult térségi szinthi elemzés az MTA RKK Budapesti Osztályán, s e kutatások eredményeit természetesen alapinformációként kezelem. Kistérségek Pest megyében 1993, Gazdasági és társadalmi folyamatok Pest megyében, 1995.

${ }^{13}$ 1994-ben az egy adózóra jutó jovvedelem nagysága Solymáron $474.067 \mathrm{Ft}$, magasabb a statisztikai agglomerációs városok (403.199 Ft) és kơzségek (345.710 Ft) átlagánál éppúgy, mint a PiliscsabaSzentendre statisztikai térségre $(375.603 \mathrm{Ft}$ ) jellemzỏ átlagos jôvedelemnagyságnál (Solymár ezen statisztikai térséghez kerult besorolásra). Forrás: Bihari Zsuzsanna által ơsszeállitott és kezelt Pest megyei adatbázis. MTA RKK Budapesti Osztály

14 A teljesség igénye nalkul: Helytorténeti Társaság, Heimatverein-Falukßr, Waldorf egyesület, Környezetvédôk Egyesülete, telepúlésrészi egyesületek, Caritas, Templom tér Alapitvány, Helytơrténeti Alapítvány, Golgota Alapitvány, Szabad Waldorf Alapítvány, Solymár Közbiztonságáért Alapítvány, Solymár Sportjáért Alapítvány, Kömyezetvédelmi Alapítvány, Corvinus Alapítvány, Református Egyházi Alapitvány. A faluban jelenleg négy kớrus és két tánccsoport múkơdik az iskolán kivul, német és angol nyelvü színjátszó stúdió, nyugdíjas klub a müvelơdési hảzban.

${ }^{13}$ A solymári sportélet a PEMÜ-n belul bontakozott ki, kézilabdacsapata NB l-es szintre jutott el. Ma is a PEMÜ RT a községi sportélet legfóbb szponzorálója, a sportalapitvány elnöke az RT elnökvezérigazgatója. A gyár sportcsarnoka pedig egyben a községé is, minden telepulési rendezvény számára szinteréul szolgál.

${ }^{16}$ A községi infrastruktúra kiépulésének Seres István kủıon, bőségesen adatolt fejezetet szentel idézett munkájában, melyet e bekezdésben is alapvetỏ forrásként kezelek.

${ }^{17}$ Forrás: lásd 7. jegyzet

${ }^{18}$ Tamás Enikõ: "Mi lesz veled, Solymár?" Solymári Hírmondó 1993. szeptember

${ }^{19}$ Seres István id. mu, 143-147. o.

${ }^{20}$ Solymári Hírmondó, 1995. július 
${ }^{21}$ Karácsony taján a pékség szakuzletében ingyen ill. kedvezményes áron juthatnak kenyérhez, péksuteményhez a solymári vásárlók, a vállalkozás születésnapján széleskơrủ fogadást adott a tulajdonos, aki nem csupán a vállalkozók és az ơnkormányzat közőtt tơlt be kőzvetitö szerepet, hanem magára vállalta a kornyezetvédők egyesületének képviseletét is.

${ }^{22}$ Solymár 1996-ban 478.737 ezer forintból gazdálkodott, a helyi adókból befolyó đsszeg 53.200 ezer Ft volt. 3640 lakos után 91.745 ezer Ft származott a személyi jovedelemadoboból, az állami támogatás egyúttes összege 210.897 ezer Ft volt, az osszes bevétel 40\%-a. Solymári Hírmondó 1996. április

${ }^{23}$ A Solymári Búcsút értékelve a Királyi Morzsák tulajdonosa, egyben a szervezỏ bizottság vezetöje, egyesuleti tag és önkormányzati képviselö "orơmteli eredményröl számolt be: a kơzség vállalkozói soha ilyen nagy számban és nagy ơsszegben nem szponzoráltak hasonló rendezvényt". A vállalkozók 3 millió forinttal támogatták a Búcsú eseményeit. Solymári Hírmondó 1997. szeptember.

${ }^{24}$ Seres István id. mú. 218-222, 0.

${ }^{25}$ 1991-ben a zsámbéki üzemegység 306 embert foglalkoztatott, Cegléden ill. a ceglédi uzemhez kapcsolódó Mikebudán és Nyársapáton 407 ill. 34 és 43 fỏ dolgozott. Forrás: Ipari telephelyi adatok, 1991. KSH, MTA RKK BO. 1991-ben a zsámbéki üzemegység 306 embert foglalkoztatott, Cegléden ill. a ceglédi uzemhez kapcsolódó Mikebudán és Nyársapáton 407 ill. 34 és 43 fó dolgozott. Forrás: Ipari telephelyi adatok, 1991. KSH, MTA RKK BO.

${ }^{26}$ Az MRP-törvény szerint a kơzós vállalatokban, így a PEMÜ vegyes tulajdonú kft-iben dolgozók nem lehetnek az MRP-tagjai.

${ }^{27}$ Seres István id. mủ 75-77. o. Az ún. B-típus bevezetése ellen, a kỏzség akkori sváb származású, magyar érzelmú plébánosának kezdeményezésére, tiltakozott a szomszédos Pilisvörösvár képviselötestülete is, szintén sikerrel.

${ }^{28}$ Kovács Alajos: A németek helyzete Csonka-Magyarországon a statisztika megvilágításában. Budapest, 1936.

${ }^{29}$ A kéziratot a jelentést készítő és Solymáron hétvégi házzal bíró Dobrovits Sándor (1939-1945-ig a KSH elnöke) adta át Seres István VB-titkárnak.

${ }^{30} \mathrm{~A}$ parasztcsaládokban szokás volt egy fiú kitaníttatása.

${ }^{31}$ Minden eshetöségre folkészulve a kisebbségi onkormányzati jelöltek mellett a Heimatverein-Falukör elnöknőjét nemzetiségi jelöltként indították a telepulési képviselötestuletben, hogy ott is legyen, aki képviseli a kisebbség érdekeit. A kezdeti zavar után ez a képviselőnő rendes képviselöként dolgozik a testuletben, minden német nemzetiséget érintő ügyben a német kisebbségi ơnkormányzat a kompetens és legitim képviselö.

${ }^{32}$ Ugyanakkor jellemző, hogy a választási csoporthoz tartozó egyik jeloltt, tanárember, nem vállalta a polgármester-jelolltséget, mert nem sváb. Ö lett a polgármester helyettese.

${ }^{33}$ Az 1990-es Népszámlálás adatai szerint a kozség lakosainak 19,7\%-a német nemzetiségü ill. beszél németül.

${ }^{34}$ Solymári Hírmondó 1996. szeptember

${ }^{35}$ A müvelödési ház emlékezỏ kiadványa az átéltekről készitett interjúkat kơzőlt, és az interjúk készitỏje néhány betelepitett felvidéki magyart is megszoblaltatott.

${ }^{36}$ Görgey Gábor író kiállítás-megnyitójának szövege. Solymári Hírmondó 1996. szeptember

\section{Irodalom}

Seres István (1993) Solymár története és néprajza. Helytörténeti Alapitvány, Solymár, Solymári Hírmondó 1989 ösze és 1997 ösze között megjelent számai.

Öszinte szándékkal. Kitelepítés 1946. április 18. és 23. Mit ehrlichem Willen. Vertreibung 18. und 23. April 1946. Apáczai Csere János Múvelodési Háza, 1996.

Segitségükért, az általuk nyújtott információkért köszönettel tartozom alább fölsorolt beszélgetôtársaimnak:

Behovics Antalné, a Hunyadi Mátyás Általános és Zeneiskola igazgatoja,

Bognár Istvánné, Solymár utolsó tanácselnöke, a Solymári Hírmondó szerkesztöje, az Apáczai Csere János Müvelödési Ház vezetője,

Budavári Mihályné, nyugalmazott fớkőnyvelô, ơnkormányzati kẻpviselö, a Heimatverein-Falukơr elnőke, a római katolikus egyházkőzség képviseloje,

Enczmann Lászlo, polgármester, a Solymári Férfikórus tagja,

Friedrich Istvánné, nyugalmazott pedagógus, a solymári tánckultúra elinditója, 
Dalos János, muianyagipari vállalkozó, gazdálkodó, az Érdekegyeztető Fónum elnơke,

Kelemen Istvánné, nyugalmazott ének- és zenetanár, a solymári kórusélet újraélesztōje, a Solymári Daloskőnyv szerzője,

Ligeti Ágnes, a Solymári Kơrnyezetvédó Egyesulet tagja, az Ezerjofú gyógynơvényszakuzlet tulajdonosa,

Lutz Ferenc, számítástechnikus, a SNKÖK tagja,

Marlokné Cservenyi Magdolna, általános iskolai tanár, a SNKÖK, a Hagyományörző Asszonykórus tagja,

Miklóssy Barna Béla, nyugalmazott nyomdász, a református egyházkozség presbitere,

Novoszádek János, pedagógus, alpolgármester,

Pakó Károlyné, vezeto óvónö, a SNKÖK tagja,

Posovszky Märton, épitési vállalkozó, a Vállalkozók Egyesületének elnőke,

Posovszky Mártonné, az ingatlaniroda vezetője, a Solymári Nőikar tagja,

Reményi István, nyugalmazott mérnök, a SNKÖK elnöke,

Sarlós Bernát, a PEMÜ RT elnok-vezérigazgatója,

Seres István, 1954 és 1988 között a kőzégi VB-titkára, a Helytơrténeti Alapitvány egyik alapitó tagja,

Solymár monográfiájának szerzője.

\section{SOLYMÁR, THE "GOLDEN VILLAGE”}

\section{MÓNIKA VẢRADI}

Development of Solymár, a prosperous village in the vicinity of Budapest has been determined by its geographical situation since the beginning of the $19^{\text {th }}$ century. Although, the settlement was part of the expanding agglomeration of the Capital, local economic basis such as fruit growing and building material industries emerged as important element of prosperity. This limited economic independence was preserved also in the centrally planned system, as a result of the establishment of new local industries such as clothing and plastic manufacturing. In this way, Solymár has always been less dependent on the economy of the metropolis than the rest of the agglomeration belt.

Despite the temporary decline in local industries, re-organisation of the privatised companies and the expansion of new enterprises (particularly, in trading, food industry and construction) strengthened local economic basis. The prosperity rested on local industrial basis, vicinity of a large-scale market furthermore, on the advanced infrastructure system (including gas and sewage).

Urban sprawl also had a significant role in local development. The process commenced with the 1950ies is still going on. The majority of immigrants are wealthy and/or highly qualified people who are important actors of local economy, act as well-to-do consumers and represent local interests in social organisations. One of the key factors of the success of Solymár is the integration of immigrants thtough the conciliation of interests of "natives" and "newcomers". In this way, traditions and cultural character of the village was preserved. German population had an important part in saving local identity.

Successful policies of the local government were also an important tier for local prosperity. This factor is based on the collaboration of the government, social organisations and local entrepreneurs. Access to information, recognition of mutual interests and permanent co-operation are fundamental for smooth operation of a successful settlement like Solymár. 